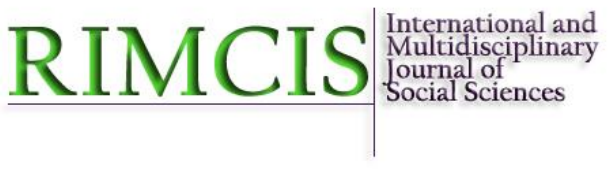

\section{Hipatia Press}

www.hipatiapress.com

Instructions for authors, subscriptions and further details:

http://rimcis.hipatiapress.com

\title{
Siege of Violent Crimes through Economic Complexity and Institutions
}

Ghulam Rasool Madni ${ }^{1}$, Bismillah Khan ${ }^{1}$

1) University of Lahore, Pakistan

Date of publication: July $30^{\text {th }}, 2019$

Edition period: July 2019 - November 2019

To cite this article: Madni, G.R., \& Khan, B. (2019). Siege of Violent Crimes through Economic Complexity and Institutions. International and Multidisciplinary Journal of Social Sciences, 8(2), 146-163. doi: 10.17583/rimcis.2019.4147

To link this article: http://doi.org/10.17583/rimcis.2019.4147

\section{PLEASE SCROLL DOWN FOR ARTICLE}

The terms and conditions of use are related to the Open Journal System and to Creative Commons Attribution License (CC-BY). 


\section{Siege of Violent Crimes through Economic Complexity and Institutions}

Ghulam Rasool Madni

University of Lahore
Bismillah Khan

University of Lahore

\section{Abstract}

This study is an effort to explore the determinants of violent crimes by using the panel data of 34 countries covering the time span from 2000 to 2014. The robust least square technique is applied for empirical analysis. The findings of the study reveal that the economic complexity, institutions and per capita income have significant negative impact while economic misery and population growth have significant positive relationship on violent crimes. Moreover, efficient institutions have prime importance to curb the crimes in a society. The better provision of knowledge and highly skilled labor force in an efficient institutional environment for alleviation of crimes is suggested as a policy tool. Additionally, serious efforts to decrease the economic misery and population growth are need of the hour to overcome the crimes.

Keywords: crimes, economic complexity, institutions, economic misery 


\section{Abordaje de los Crímenes Violentos a partir de la Complejidad Económica y de las Instituciones}

Ghulam Rasool Madni

University of Lahore
Bismillah Khan

University of Lahore

\section{Resumen}

Este estudio es un esfuerzo para explorar los determinantes de los crímenes violentos usando datos del panel de 34 países durante el lapso de tiempo que va de 2000 a 2014. Para el análisis empírico se ha utilizado la técnica de los mínimos cuadrados robustos. Los resultados del estudio muestrran que la complejidad económica, las instituciones y los ingresos per capita tienen impactos negativos significativos mientras que la miseria económica y el crecimiento de la población tienen relación positiva significativa con los crímenes violentos. Más aún, las instituciones eficientes tienen una importancia capital para reducir los crímenes en una sociedad. A fin de reducir el crimen los resultados sugieren como herramienta política una mejor provisión de conocimientos y una fuerza de trabajo altamente cualificada en un entorno institucional eficiente. Adicionalmente, para superar el crimen también son necesarios serios esfuerzos para reducir la miseria económica y el crecimiento poblacional.

Palabras clave: crímenes, complejidad económica, instituciones, miseria económica

2019 Hipatia Press

ISSN: 2014-3680

DOI: $10.17583 /$ rimcis.2019.4147 
ny act that will be against the law or that has been prohibited by law for the security of the public is called a crime (Marshall \& Clark, 1952). Crime is an engrossed topic in recent research work across the countries and becomes a substantive and considerable issue in the debates of recent time. Criminals commit a crime not by single reason, but there are many reasons due to which criminals are compelled to commit crimes like social issues, economical stress and domestic tensions. Authors have been checking the relationship between the crime and economics since 1960's, when Fleisher (1966) predicted that the crime rate increases when the unemployment and low per capita income increases. Becker (1968) is of view that individual will commit a crime if the expected utility that will be derived from criminal activity exceeds the expected cost of crime. Ehrlich (1975) leads Becker's rational model for crime and predicted that a devotion of time to lawful and unlawful activity may also affect the crime rate. Gumus (2004) argued that most consequential determinants that may affect the crime rate as socioeconomic factors are population, police expenditure, primarily black community. Unemployment is also a socioeconomic factor that has a positive relationship with crime rate both in time series and in cross sectional data (Edmark, 2005); Lin (2008); Oster and Agell (2007). Savolainen (2000) developed a hypothesis to test the negative interaction impact between strength of welfare state and economic inequality. It is showed that economic inequality is a strong reason for homicide rate in countries associated with weak institutional quality of social protection. Lafree (1998) highlighted that crime rate was increased in 1960 due to the weaknesses of political institutions, increasing fear produced by economic institutions and due to weak quality of social institutions.

If we have a look on crimes across the world, the situation is not satisfactory. The Global Economic Crime and Fraud Survey (Lavion, 2018) has recognized that, the economic crime (robbery, cyber crime, abuses of economic aid, selling of controlled goods and tax evasion) has been increased in 2018 approximately in all territories. In 2018, 49\% of respondents to Global Economic Crime and Fraud Survey said their companies had been victims of fraud or economic crime, up from $36 \%$ in 2016. A global picture of economic crime rate in companies is reported in following table 1 . 
Table 1.

Regional Percentage Rise of Economic Crimes in Organizations (Lavion, 2018)

\begin{tabular}{lll} 
Region & $\mathbf{2 0 1 6}$ & $\mathbf{2 0 1 8}$ \\
\hline Africa & $57 \%$ & $62 \%$ \\
Western Europe & $28 \%$ & $53 \%$ \\
Eastern Europe & $33 \%$ & $47 \%$ \\
Asian Pacific & $30 \%$ & $47 \%$ \\
North America & $37 \%$ & $54 \%$ \\
Middle East & $25 \%$ & $35 \%$ \\
\hline
\end{tabular}

On the other hand, the condition of violent crime like homicide (deliberately killing of someone) is fearful. The United Nations (2012) demonstrate that the intentional murder (homicide) rate was around 437000 annually, the lowest and highest homicides recorded in Oceania and USA respectively. If we want to diminish the homicide rate for coming three decades by 50 percent, then we have to reduce the homicide rate by 2.3 percent annually (Eisner, 2003).

Keeping in view the literature and facts about crime, this study has intention to analyze the role of economic complexity, not explored before. Economic complexity shows the sophistication of country's knowledge, knowhow, skills and productivities that are absorbed by the export of countries. Two factors are necessary for the economic complexity; the diversity of a country-how many products for export country does make and the ubiquity of export product - how many countries have made the same product. If a country makes many products then a country will be considered economically diversify while if a product has been made by only few countries then that product will be considered ubiquitous product for export (Hidalgo \& Hausmann, 2009). It can be hypothesized that economic complexity may enhance the economic growth and increased economic growth may lead to decrease the crimes so it is interesting to determine the empirical relationship between these indicators. The institutional role to deteriorate the crime rate will also be helpful for policy makers for establishing a peaceful society. Moreover, Clark et al (2017) have pointed out that there are two conditions in which humans are inhabited; misery and happiness. Misery comes through high inflation, high unemployment and 
with steep borrowing cost while happiness relates to strong and high economic growth, low inflation and with plentiful employment.

At present most of the criminal justice researchers and organizations have focused on crime. Despite of the fact that, we have declared the world a global village but the crime (violent as well as economic) is at its peak in some countries. Researchers feel difficulty while analyzing the impact of socioeconomic and demographic factors on crime rate across countries because countries depict the crime rate according to their own visions. But only the homicide rate is a crime that has same definition in each country. In spite of this, there is still gap in literature to determine the relationship between crimes, economic complexity, institutions and economic misery; prime objective of the study.

\section{Literature Review}

It is very important to relate proposed research to the primal works in economics and in statistics because it portrays the connection and originality of problem. There is an immense literature related to crime but some fruitful convincing studies have been used for the study. The following studies shed some light upon the existing literature on crimes and their findings but after this review, we come to know that there is hardly any study that explores the impact of economic complexity and institutional quality on violent crimes. So, this study is an effort to investigate the impact of economic complexity on crimes by considering the panel data analysis and will be helpful to combat the violent crimes in a country.

Becker (1968) is pioneer of this branch of economics by developing an economic model of crime while Ehrlich (1973) expanded this model and incorporated both punishment and reward factors. According to them, crime rates depend on the risks and penalties associated with apprehension and also on the difference between the potential gains from crime and the associated opportunity cost. Basically, the model suggests that crime can be affected by socio-cultural factors, crime deterrence policy factors and economic inequality.

Anwar et al (2017) analyzed the relationship between crime and socioeconomic determinants of crime. They used the time series data from 
1973 to 2014. The dependent variable is crime while the regressors for the study are deterrent variable, income inequality, per capita income, education and unemployment. They used the autoregressive distributive lag model and error correction model as estimation techniques for finding the short run and long run relationship between the explained and explanatory variables of the study. Deterrence variable for the study is the strength of the police. Findings of the study show that in the long run, all the regressors are significantly effective. The study shows that error correction model signs of coefficient are also significant. It shows the movement towards equilibrium in the long run.

Asongu and Ayani (2018) have collected the data for 163 countries for the years from 2010 to 2015 as a sample for the study. They used generalized method of movement for the findings. They have concluded that Sub Saharan Africa is on the top in homicide rate, the Latin America is second in ranking of homicide, the MENA countries are on number 3, while ECA countries are on number 4 across the sample. They categorized the data into level of income; land lockedness, religious and legal origins. They predicted that the political instability, crime and imports of weapons have a positive relation to violent crime while the police officers and security measures have negative impact.

Islam (2016) has analyzed the crime rate in developing countries. As a sample, he used different developing countries of the world like South Africa, Eastern Europe, and Asia etc. The author categorized the rural crime into three different types, violent crime, environmental crime and corruption and found that the rural crime in developing countries is higher than the crime of the developed nation's rural areas. The livestock theft is very common in rural areas. Author argued that life is so risky in rural areas of developing nations but the evidences of these crimes are very low because of scarcity of data. It is also mentioned that rural crime is very dangerous for the sustainable development of rural segments of countries. This crime may have impact on their food security, reduces the access to public facilities and may insecure their income. This crime also has many other costs like the people of rural areas used their money in security measures to safe themselves from criminals. They may use this money in other businesses in future. 
Nagin et al (2009) analyzed the impact of imprisonment on reoffending the crime as imprisonment is the severe punishment in democratic countries for crime prevention. They are of view that there are many ways through which imprisonment is affecting reoffending. Crime rate may be reduced by some combination of specific deterrence and rehabilitation. They argued that reoffending a crime by a person depends upon the social and personal characteristics. So, deterrence policy for crime control might be preventive or criminogenic impact. Authors conclude that "Compared with noncustodial sanctions, incarceration appears to have a null or mildly criminogenic effect on future criminal behavior. This conclusion is not sufficiently firm to guide policy generally, though it casts doubt on claims that imprisonment has strong specific deterrent effects. The evidence does provide a basis for outlining components of an agenda for substantive and policy relevant research."

Habibullah and Bahroom (2009) have collected the data of Malaysian crime for the years from 1973 to 2003. The study investigates two different relationship and impacts (i) how the categories of crime effect the income inequality (ii) how income inequality impacts the different categories of crime. In this study, they used the autoregressive distributive lag (ARDL) model for the estimation of results as an estimation technique. Their outcomes for both the relationships show that, disparities in income have no impact on property crime, violent crime, robbery and theft while the total crime also has no impact on income inequality. The policy suggestion of this paper is that the government has to reduce the income inequality or to stabilize it up to some minimum limit. Otherwise this may increase the crime rate in the long run.

Dutta and Husain (2009) examined the impact of economic growth, income inequality and urbanization on crime rate. They collected the panel data for post liberalized India from 1999 to 2005 . They got their results by the use of fixed effect model. Their inferences portray that economic growth is very important factor for the curtailing of crime rate because it has negative and significant relationship with crime rate. While increasing urbanization and income inequality are the accelerators of the crime rate. They suggested a policy that the government have to increase the economic growth and have to reduce the inequality for the curtailing of crime rate. The 
trickledown effect and sustainable economic growth, both are complementary for crime reducing. The trickledown effect makes the economic growth more effective because with this the poor segment can also get access to the benefits of economic growth. Without trickledown effect, the rising of economic growth is meaningless.

Sung (2004) investigated that with the help of education we can reduce the organized crime because education increases the employment opportunities for a person. But with this, we cannot reduce the crime rate because we are well aware that most of the corruption has been doing in service sector while most of our educated people go to service sector. Here Sung did not perceive the advantages of education very well. Because education for employment is considered just as a source for getting the job. Education may decrease the level of crime when it brings internal change in you. Education may build up your moral level and personality. Employment may just a factor that lead the individual from illegal to legal work. But the opportunities for organized crime also prevail in legal sectors of the economy.

The above literature has used the impact of socioeconomic and demographic factors on crime rate. Their findings show that the favorable factors like GDP, employment, institutions, education and number of police have negative relationship with crime rate. The unfavorable factors population density, urbanization, unemployment, income inequality and poverty have positive relationship with crime rate while economic complexity is a factor that is still unaddressed in the literature and the prime objective of this study.

\section{Data Description and Methodology}

This part of the study consists upon description of the data and the methodology adopted for the empirical analysis. The sample size is based on provision of empirical data. Panel data has the ability to deliver efficient parameters and highlights more complex actions of entities. We have selected the secondary panel data of 34 countries for 14 years from 2000 to 2014. 
Crime rate is the dependent variable of the study. The homicide rate per 100000 is a proxy that has been constantly used for crime rate in studies like Ouimet (2012) and Coccia (2017). A number of reasons justify the fact that, why researchers have used the homicide rates as a proxy for crime. First because it is very difficult to put out of sight the dead bodies, and for that it is effortlessly familiar to the authorities. The second reason is that the definition across countries for homicide is same. While, the final reason is that the homicide is the suitable needle and pointer for general violence, because the end results of many crimes is homicide.

Economic complexity index collects the information of the countries diversity (amount of products they exported) and ubiquity (the number of countries that export that product) and then measures the efficient productive structure of a country. The data for economic complexity index has been collected from observatory of economic complexity ${ }^{1}$.

Economic misery index is a simple index which is the summation of annual inflation and annual unemployment. To measure economic misery, an index proposed by Okun (1970) is used for analysis by summation of unemployment and inflation.

Institutions are set of formal rules and informal norms and their role for economic performance cannot be negated. According to Madni (2019), "efficient and effective institutions matter for enhancing the investment levels, higher social capital stock of a society, better policies, and effectual control on social violence, conflicts and ethnic diversity." An index for institutions is constructed through Principal Component Analysis (PCA) considering the six indicators of institutions given by World Governance Indicators. In PCA, orthogonal transformation is carried out through conversion of highly correlated variables into non correlated linear variables. In this statistical procedure, data is normalized for Eigenvalue decomposition of data covariance matrix. The normalization of every variable is performed through subtraction of individual value from mean value of that variable so variance of variable is equal to 1 . The outcomes of PCA are called factor scores or component scores and loadings. Factor scores are the transformed values of variable with respect to specific data point while loadings are the weights that are multiplied by standardized 
variable to obtain the factor score. These weights are eigenvectors and cosines of orthogonal rotations into principal components.

Population growth is the annual percentage growth rate on the base of definition of World Bank, which counts all the residents of country regardless of legal or citizenship.

The basic model for a crime was first time given by Becker (1968) by arguing that criminal commit a crime after making a cost and benefit analysis for that crime. If the expected benefit relates to crime exceeds the expected cost of the crime, and then a person will commit a crime. Benefit of a crime means the monetary value of the crime while the cost of a crime is punishment, fine and a time that will spend in jail.

We used the approach of rational choice model that was given by Bentham (1789) and Beccaria (1764). This model has also been used by Donxu and Zhangmin (2012) for a crime analysis. We know that there are two ways for earning income; legal and illegal way. We suppose that the criminal is a rational person and use these two ways of earning as a choice. An individual, who wants to maximize its utility by illegal way, will commit a crime if the expected utility exceeds the utility that would gain from legal way of earning.

$$
\mathrm{EZ}_{\mathrm{C}}>\mathrm{EZ}_{\mathrm{L}}
$$

Here $E Z_{C}$ is the expected utility from a crime while $E Z_{L}$ is the expected utility from legal way. $E Z_{C}$ is a function of expected cost benefit from the criminal way and the degree of risk aversion. Different crimes having different returns for that degree of aversion has a vital importance. If the criminal decides to carry out a crime, then it will be upset between two situations; it may be arrested with a chance $B$ or may be escaped with a chance $1-B$. For that $E Z_{C}$ is a chance weighted average of the two states utility.

$E Z_{C}=(1-\beta) Z\left(M_{C}, N\right)+\beta Z\left(M_{C}-H, N\right)$

This is a Von-Neumann-Morgenstern utility function.

$\mathrm{M}_{\mathrm{C}}$ is the monetary returns of the crime, $\mathrm{H}$ is the cost of foreboding (time in jail, fine, punishment) etc. Because a peaceful crime for criminal requires a 
long time and master mind for that $\mathrm{N}$ is the struggle and tension cost of crime.

By taking the derivative of equation (2) with respect to $\beta$, then the equation will become

$$
\frac{\partial \mathrm{EZC}}{\partial \mathrm{S}}=-\mathrm{Z}\left(\mathrm{M}_{\mathrm{C}}, \mathrm{N}\right)+\mathrm{Z}\left(\mathrm{M}_{\mathrm{C}}-\mathrm{H}, \mathrm{N}\right)<0
$$

By taking the derivative of equation (2) with respect to $\mathrm{H}$

$$
\frac{\partial \mathrm{EZC}}{\partial \mathrm{H}}=-\beta Z^{\prime}\left(\mathrm{M}_{\mathrm{C}}-\mathrm{H}, \mathrm{N}\right)<0
$$

Equation (4) shows that, if the chances of arrestment $B$ and the cost of foreboding $\mathrm{H}$ will be higher the crime rate will fall.

An econometric model can be developed from the above equation (2) by putting the potential variables affecting the crime rate like economic complexity, economic misery, institutions, per capita income and population growth. For this, expected utility of each independent variable can be compared with the expected utility of crime. If the expected utility from crime exceeds the expected utility of independent variables, then it will be considered for regression analysis. After analysis of each independent variable, following an econometric model is derived.

$$
\mathrm{CR}_{\mathrm{it}}=\beta_{1 \mathrm{i}}+\beta_{2} E C_{\mathrm{it}}+\beta_{3} \mathrm{EM}_{\mathrm{it}}+\beta_{4} \mathrm{INS}_{\mathrm{it}}+\beta_{5} P G_{i t}+\beta_{6} P C Y_{\mathrm{it}}+\mathrm{G}_{\mathrm{it}}
$$

Here CR shows the crime rate, EC shows the economic complexity, EM is the economic misery, INS indicates the institutional index, PCY stands for gross national product per capita and PG is the abbreviation of the population growth.

Robust Least Square is applied for the purpose of estimation.

\section{Empirical Findings and Their Description}

The Levin, Lin, Chu test for the stationarity is applied. Rejection of null hypothesis means that the data is stationary while the acceptance of null 
hypothesis means that data is non stationary. All of the variables are stationary at level at one percent level of significance.

Table 2.

Levin, Lin, Chu Stationarity Result

\begin{tabular}{lccc} 
Variables & S. Values & P. Values & Levels \\
\hline Violent Crime & -7.874 & 0.0000 & $* * *$ \\
Economic Misery & -2.612 & 0.0000 & $* * *$ \\
Institutions & -13.605 & 0.0000 & $* * *$ \\
Economic Complexity & -5.400 & 0.0000 & $* * *$ \\
Per Capita Income & -6.589 & 0.0000 & $* * *$ \\
Population Growth & -10.393 & 0.0000 & $* * *$ \\
\hline
\end{tabular}

Note:*** shows the stationarity at level.

After finding the stationarity of variables, robust least square estimation technique is applied. The dependent variable is the violent crime (homicide rate) while the independent variables are economic complexity, economic misery, institutional index, per capita income and population growth.

The probability values of the model show that all the variables are significant at one percent level of significance except the per capita income. The signs of all the variables are consistent with economic theory. The economic complexity has a negative relationship with crime rate. As economic complexity is the total of knowledge and technical knowhow that is embodied in the productive sectors of the economy so countries with high economic complexity have skilled labor force and high knowledge with less chances of unemployment. So, a person with high knowledge and high skills is less likely to commit a crime. The findings are also supported by Hidalgo and Hausmann (2009).

The institutional quality has strong negative relationship with crime. By improving the efficiency of institutional quality, criminals have fewer chances to be escaped from punishment. The efficient institutional structure will bring down the level of committing crime in a society. The outcomes of the study are also consistent with findings of Khan et al (2015).

The positive relationship between economic misery and crime rate can be observed in findings of the study. Torruama and Abur (2014) have also concluded that inflation and unemployment have a long run positive 
relationship with crime rate. The results of economic misery also show consistency with the earlier studies on topic.

Table 3.

Empirical Results of Robust Least Square

\begin{tabular}{lllll} 
Variables & Coefficient & Std. Error & z-Statistics & Prob. \\
\hline C & 1.044 & 0.143 & 7.27 & 0.0000 \\
Economic Complexity & -0.394 & 0.086 & -4.53 & 0.0000 \\
Per Capita Income & -0.006 & 0.011 & -0.55 & 0.5759 \\
Economic Misery & 0.016 & 0.005 & 2.827 & 0.0000 \\
Institutions & -0.686 & 0.068 & -10.09 & 0.0000 \\
Population Growth & 0.268 & 0.05 & 4.89 & 0.0000 \\
& & & & \\
\hline
\end{tabular}

The relationship between population growth and crime is positive. As population increases, the crime rate also increases. Neumayer (2003) argued that high population accelerates inequalities and delivers more opportunities for the criminals to commit a crime. While per capita income is negatively insignificant but the statistical sign satisfying the economic theory that it has negative relationship with crime rate. The insignificant sign may be due to low level of incomes that may have no attraction to avoid the crimes in a society of luxuries and show off.

\section{Conclusions}

The first aim of this study was to find out the impacts of economic complexity and institutions on a violent crime rate (homicide). From estimated inferences, it can be concluded that, economic complexity and institutions are playing vital role to combat crimes in an economy. The economic complexity has also negative relationship with crime rate so the acceleration of economic complexity will reduce the crime rate. It is very important to equip the labor force with high quality of knowledge and technical knowhow. With the help of which, they may become more 
productive and skillful. Labor force with high knowledge and high skills are less likely to commit a crime.

If we increase the efficiency of institutions, it will lead to reduce the crime rate up to certain limit. With efficient institutions, the chances of apprehension for the criminal increase because efficient institutions make the law enforcement mechanism more effective. There are many other aspects with which institutions can become a source for the curtailing of crime. With the help of efficient institutions, we can ensure the trickledown effect in the country.

The economic misery also has positive and significant relationship with crime rate. It can be perceived that increase in economic misery will create an upward movement in crimes. Inflation reduces the purchasing power of the individuals by reducing their real money balances. While, unemployment is the source of anxiety, which makes individual to forgets the certitude of castigation and compels the individuals for committing crime. Population growth is also a factor leading to raise the crimes in a society. High population growth provides more opportunities for the criminals to commit a crime. Because in high population it is very difficult for the security authorities to keep check and balance on the criminals. The second side effect of the high population is that, it accelerates inequalities and enlarges the gap between the poor and rich. This makes the poor deprivable from the decision making and engulfed them in a vicious circle of poverty and poverty compels the man to commit a crime for financial gains to stabilize his life.

\section{Notes}

${ }^{1}$ Please for detail visit: https://atlas.media.mit.edu/en/rankings/country/eci/

\section{References}

Anwar, A., Arshad, N., \& Anwar, S. (2017). Socioeconomic Determinants of Crime: An Empirical Study of Pakistan. International Journal of Economics and Financial Issues, 7(1), 312-322. 
Asongu, S.A., \& Acha-Anyi, P.N. (2018). The Murder Epidemic: A Global Comparative Study. International Criminal Justice Review, 24, 285297. doi: 10.2139/ssrn.3109974

Beccaria, C. (1764). On crimes and punishments (H. Paolucci, 1963, Trans.). New York, NY: Pearson Education Limited.

Becker, G. (1968). Crime and punishment: An economic approach. Journal of Political Economy, 76, 169-217. doi: 10.1007/978-1-349-628537_2

Bentham, J. (1789/1970). Introduction to the principles of morals and legislation. (J.H. Burns \& H.L.A. Hart (Eds.)) London, England: Athlone Press. doi: 10.1093/oseo/instance.00077240

Blanco, L., Ruiz, I., Swayer, W.C. \& Wooster, R. (2015). Crime, Institutions and Sector-Specific FDI in Latin America. Economics Faculty Publications and Presentations. Paper 47. doi: 10.2139/ssrn.2607682

Chatterjee, I. \& Ray, R. (2009). Crime, Corruption and Institutions. Monash Economics Working Papers 20-09, Monash University, Department of Economics.

Clark, A. E., Fleche, S., Layard, R., Powdthavee, N., Ward, G. (2017). The Key Determinants of Happiness and Misery. CEP Discussion Paper No. 1485.

Coccia, M. (2017). A Theory of General Cause of Violent Crime: Homicide, Income Inequality and Deficiencies of the Heat Hypothesis and of the Model of Clash. Aggression and Violent Behavior, 37, 190-200. doi: 10.1016/j.avb.2017.10.005

Donxu, W., \& Zhongmin, W. (2012). Crime, Inequality and Unemployment in England and Wales. Applied Economics, 44(29), 3765-3775. doi: 10.1080/00036846.2011.581217

Dutta, M. \& Husain, Z. (2009). Determinants of crime rates: Crime Deterrence and Growth in post-liberalized India. MPRA paper 14478.

Edmark, K. (2005). Unemployment and Crime: Is there a Connection. Scandinavian Journal of Economics, 107(2), 353-373. doi: 10.1111/j.1467-9442.2005.00412.x

Ehrilch, I. (1975), On the relation between education and crime. In F.T. Juster (Ed.), Education, Income, and Human Behavior. New York: McGraw-Hill. 
Ehrlich, I. (1973). Participation in illegitimate activities; a theoretical and empirical investigation. Journal of political Economy, 81(3), 521 565. doi: 10.1086/260058

Eisner, M. (2003). Long-term historical trends in violent crime. Crime and Justice; A Review of Research, 30, 83-142. doi: 10.1086/652229

Fleisher, B. (1966). The effect of income on delinquency. The American Economic Review, 56(1/2), 118-137. doi: 10.1037/e438152008-016

Gümüș, E. (2004). Crime in urban areas: An empirical investigation. Akdeniz I.I.B.F. Dergisi, 4(7), 98-109.

Habibullah, M.S., \& Baharom, A.H. (2009). Crime and economic conditions in Malaysia. International Journal of Social Economics, 36(11), 10711081. doi: $10.1108 / 03068290910992624$

Hidalgo, C., \& Hausmann, R. (2009). The Building Blocks of Economic Complexity, Proceedings of the National Academy of science, 106(26), 10570-10575.

Islam, A. (2016). An Exploration of the Relationship between Police Presence, Crime, and Business in Developing Countries. Policy Research Working Paper No. 7560. World Bank, Washington, DC. doi: 10.1596/1813-9450-7560

Khan, N., et al. (2015). The Socio-Economic Determinants of Crime in Pakistan: New Evidence on an Old Debate. Arab Economics and Business Journal, 10, 73-81. doi: 10.1016/j.aebj.2015.01.001

Lafree, G. (1998). Social Institutions and the Crime Bust of the 1990s. Journal of Criminal Law and Criminology, 88(4), 1325-1368. doi: $10.2307 / 1144258$

Lavion, D. (2018). Pulling Fraud out of the Shadows. Global Economic Crime and Fraud Survey 2018. Executive Summary. Retrieved from: https://www.pwc.com/gx/en/forensics/global-economic-crime-andfraud-survey-2018.pdf

Lin, M.J. (2008). Does unemployment increase crime? Evidence from U.S. data 1974-2000. Journal of Human Resources, 43(2), 413-436. doi: 10.1353/jhr.2008.0022

Madni, G.R. (2019). Probing the Institutional Quality through Ethnic Diversity, Income Inequality and Public Spending. Social Indicators Research, 142, 581-595. doi: 10.1007/s11205-018-1924-1 
Marshall, W.L., \& Clark, W.L. (1952). A Treatise: The Legal Definition of Crime on the Law of Crime. Chicago: Callagan and Company.

Nagin, D.S., Cullen, F.T., Jonson, C.L. (2009). Imprisonment and Reoffending. Crime and Justice, 38(1), pp. 115-200. doi: $10.1086 / 599202$

Neumayer, E. (2003). Good policy can lower violent crime: evidence from a cross-national panel of homicide rates, 1980-97. Journal of Peace Research, 40(6), 619-640. doi: 10.1177/00223433030406001

Okun, A.M. (1970). The Political Economy of Prosperity. The Brookings Institution Washington D.C.

Oster, A., \& Agell, J. (2007). Crime and unemployment in turbulent times. Journal of the European Economic Association, 5(4), 752-775. doi: 10.1162/jeea.2007.5.4.752

Ouimet, M. (2012). A World of Homicide. Homicide Studies, 16(3), 238258. doi: $10.1177 / 1088767912442500$

Savolainen, J. (2000). Inequality, Welfare State, and Homicide: Further Support for the Institutional Anomie Theory. Criminology, 38(4), 1021-1042. doi: 10.1111/j.1745-9125.2000.tb01413.x

Sung, H.E. (2004). Democracy and political corruption: A cross-national comparison. Crime, Law and Social Change, 41(2), 179-193. doi: 10.1023/b:cris.0000016225.75792.02

Torruama, J.T., \& Abur, C.C. (2014). The Relationship between Unemployment, Inflation and Crime rate: An Application of Co integration and Causality Analysis in Nigeria. Journal of Economics and Sustainable Development, 5(4), 131-137. doi: 10.14738/abr.55.3135

United Nations (2012). The Millennium Development Goals Report 2012. Retrieved from: https://www.un.org/millenniumgoals/pdf/MDG Report 2012.pdf 


\section{APPENDIX}

Countries for the study

\section{Formerly Socialist Countries}

Croatia, Czech Republic, Estonia, Poland, Romania, Hungary, Latvia

Spanish and Portuguese Speaking Countries of the Western Hemisphere (LA)

El Salvador, Costa Rica, Panamá, Venezuela, Guatemala, Colombia

\section{Established Market Economies}

Austria, Finland, Greece, Italy, Japan, Netherland, Portugal, Norway, Spain, United Kingdom, United States of America, Switzerland, Germany, France, Belgium

\section{Asian and other countries}

China, Thailand, Pakistan, Turkey, South Africa

Ghulam Rasool Madni is Assistant Professor at The University of Lahore.

Bismillah Khan is M.Phil graduate of The University of Lahore.

Contact Address: 1-km Thokar Niaz Baig, Raiwind Road, Lahore, Pakistan.Email: ghulam.rasool@econ.uol.edu.pk 